\title{
The Late Devonian placoderm Aspidichthys Newberry, 1873 from the Holy Cross Mountains, Poland
}

\author{
Patrycja G. Dworczak ${ }^{1}$ and Piotr Szrek $^{2}$ \\ ${ }^{1}$ Institute of Geology, Institute of Geology, Adam Mickiewicz University, 16 Maków Polnych Street, 61-606 Poznań, Poland \\ ${ }^{2}$ Polish Geological Institute - National Research Institute, 4 Rakowiecka Street, Warsaw, Poland \\ Correspondence to: Piotr Szrek (piotr.szrek@pgi.gov.pl)
}

Received: 23 June 2016 - Revised: 2 September 2016 - Accepted: 7 September 2016 - Published: 21 November 2016

\begin{abstract}
The reported placoderm remains from the Holy Cross Mountains, Poland, belong to the species Aspidichthys ingens Koenen, 1883. This study focuses on the material described in the past from Wietrznia Quarry but the new specimens were also collected form Kowala and Płucki localities. All specimens presented here differ from others described in the past, mainly by having smaller tubercles and possessing a distinctive crest in the anterior median part of the median dorsal plate, but did not allow the erection of a new taxon. Based on conodont assemblage, all specimens are attributed to a Frasnian age. Aspidichthys occurs in the middle to the upper part of the Frasnian (Palmatolepis punctata to P. linguiformis conodont zone) and is not found in the Famennian boundary. Described specimens also occur in a stepwise deepening environment caused by local synsedimentary tectonics.
\end{abstract}

\section{Introduction}

The genus Aspidichthys has an uncertain systematic position and is traditionally placed within the Arthrodira and closely related to the holonematids (e.g. Kulczycki, 1957; Schultze, 1973; Denison, 1978). It comprises large and medium-size placoderms with a distinctive elongated median dorsal plate, and well-marked large tubercles cover dermal bones. The tubercles are closely spaced and irregularly arranged. They may form rows paralleling the plate outline, usually at the margins. Plates are relatively thick (reach several centimetres). Due to these features, it is easy to recognize even partially preserved specimens of Aspidichthys, which has noticed very often by many authors, in several areas of the former Laurussia and Gondwana. Remains of Aspidichthys are known from the USA (Newberry, 1873; Sinclair and Walker,
1956; Miles, 1965); north-eastern Iran (Schultze, 1973); Morocco (e.g. Rücklin, 2010), Bad Wildungen, Germany (e.g. Gross, 1932); and the Holy Cross Mountains, Poland (Kulczycki, 1957; Ivanov and Ginter, 1997; Janiszewska et al., 2007; Szrek, 2006, 2007, 2008; Szrek and Ginter, 2007, 2008).

The main goal of this paper is to describe placoderms previously assigned to the genus Aspidichthys from the Upper Devonian of the Holy Cross Mountains and check whether they belong to this genus. First information about the occurrence of the genus of Aspidichthys in the Holy Cross Mountains was reported by Gorizdro-Kulczycka (1934) and was later published by Kulczycki (1957). Kulczycki (1957) described a median dorsal plate and nuchale plate from the Frasnian deposits of the Kadzielnia Chain (Kielce) and reported the exceptional prominent semidentine tubercles reaching more than $10 \mathrm{~mm}$ in diameter as the most important feature. He also ascertained that Aspidichthys and Anomalichthys differ from each other in size and morphology of ornamentation, and these differences are the result of the North American extent of Aspidichthys and the European extent of Anomalichthys. Nevertheless, all specimens formerly belonging of the genus Anomalichthys are assigned to the genus Aspidichthys (Denison, 1978).

The stratigraphic occurrence of Aspidichthys is limited to the Upper Devonian. Most remains have been discovered in the Frasnian, although a few specimens have been dated as Famennian (Denison, 1978). However, the Holy Cross Mountains deposits yielding Aspidichthys material are confined to the Frasnian (Kulczycki, 1957; Narkiewicz et al., 2006). 
Institutional abbreviations: WNaZ - Faculty of Earth Sciences, University of Silesia, Sosnowiec; MWG UW Faculty of Geology, University of Warsaw; Muz. PGI-NRI - Geological Museum of the Polish Geological InstituteNational Research Institute, Warsaw.

Anatomical abbreviations: lc - main lateral lines; MD - median dorsal plate; PDL - posterolateral plate.

\section{Material and methods}

The studied material comprises four median dorsal plates of Aspidichthys ingens Koenen, 1883 and was collected by Jan Czarnocki in the 1930s, and then described by Kulczycki (1957), Łukasz Gagała (personal communication, 2001), and Michał Rakociński (personal communication, 2010), as well as the present authors (personal communication, 2015). Age, locality, and measurements of specimens are listed in Tables 1 and 2. Specimens are preserved in limestone and prepared at one surface side. In all cases it is the external side. Specimen Muz. PGI-NRI 5.II.89 was described and illustrated by Kulczycki (1957, Pl. 11, Fig. 2). Specimen UW MWG ZI/43/0045 was mentioned by Szrek (2009). Specimens WNaZ/S/4/142 and Muz. PIG-NRI 1809.II.17 are described for first time. The material is incomplete but well preserved and reveals diagnostic features like ornamentation and natural margins of plates. The breadth, length, thickness of plates, height, and diameter of tubercles were measured (see Table 1). The number of tubercles on $25 \mathrm{~cm}^{2}$ has been counted as an additional character.

Two limestone samples have been taken from specimens WNaZ/S/4/142 and Muz. PGI-NRI 5.II.89 and were dated according to conodont assemblage. Each sample was about $1 \mathrm{~kg}$ in weight and was acid-prepared using $10 \%$ acetic acid. The residuum was separated using a magnetic separator at the Faculty of Geographical and Geological Sciences of Adam Mickiewicz University. Conodonts were determined using a Olympus SZH10 stereoscopic microscope.

\section{Geological setting}

The studied area is located in the western part of the Holy Cross Mountains (central Poland in the Kielce area; Fig. 1). In the studied localities, the Upper Devonian beds are well exposed. The analysed sections are described by Szulczewski (1971, Fig. 5), Racki et al. (2002, Fig. 2c), and Szrek and Ginter (2007, Fig. 7), dated as middle and upper Frasnian based on conodonts (Table 2).

The Late Devonian facies of the area studied is established on the wide carbonate platform environment, which was divided into blocks during the Frasnian and stepwise submerged (Szulczewski, 1989, 1995). The submersion of the carbonate platform was probably an effect of synsedimentary block tectonics (Narkiewicz et al., 2006; Szulczewski, 1995).
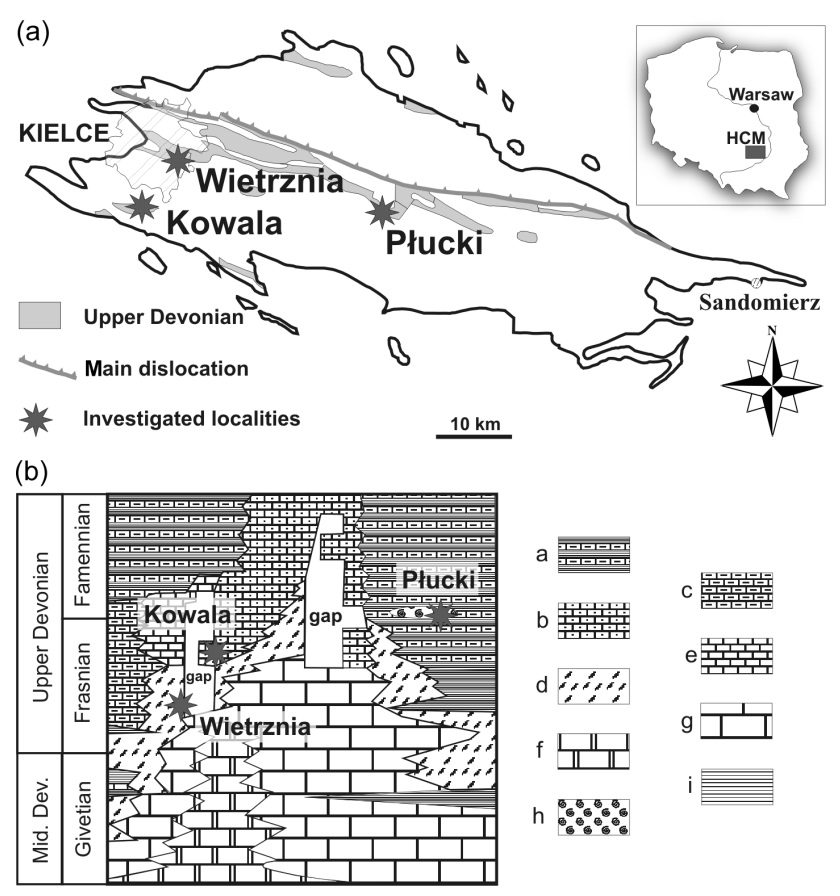

Figure 1. Location of the investigated outcrops in the Holy Cross Mountains. (a) Location map of the Holy Cross Mountains (HCM), central Poland (modified from Kowalczewski, 1971). (b) Diagrammatic cross section through the Holy Cross Mountains from the Givetian to the top of the Upper Devonian (after Szulczewski, 1995, modified) with the probable position of the localities investigated ( $\mathrm{a}$ - marly limestones and shales; $\mathrm{b}$ - condensed cephalopod and crinoidal limestones; c - marly limestones; $\mathrm{d}$ - calcirudites; e - bedded limestones; $\mathrm{f}$ - dolomites; $\mathrm{g}$ - massive and bedded limestone; $\mathrm{h}$ - cephalopod limestones; i - clayey and marly shales).

The deepening of the Devonian carbonate platform ended during the Visean and contributed to the development of a deep-sea pelagic platform (Szulczewski, 1989, 1995; Szulczewski et al., 1996).

Wietrznia (Fig. 1) is a $30 \mathrm{~m}$ deep abandoned quarry located in the south-eastern part of the city of Kielce, where the Upper Devonian beds are well exposed. Today the quarry is protected as a geological reserve. The Aspidichthys remains (Muz. PGI-NRI 5.II.89) were collected in coarse-grained crinoid limestone and come from the older collection described by Kulczycki (1957).

The second locality Kowala is a large active quarry situated about $10 \mathrm{~km}$ south of Kielce (Fig. 1). The profile exposed in the quarry comprises the Frasnian and the Famennian beds representing lithological sets A-L described by Szulczewski (1971; A-H Frasnian) and Berkowski (2002; $\mathrm{H}-\mathrm{L}$ Famennian). The sequence cropping out in the quarry of the Chęciny-Zbrza Basin shows more than $350 \mathrm{~m}$ of the profile (e.g. Racki et al., 2002). The specimens were collected in marly limestone, which is interbedded with shales (Szulczewski, 1989; Joachimski et al., 2001; Racki et al., 2002). 
Table 1. List of the studied specimens and their measurements.

\begin{tabular}{lllll}
\hline & \multicolumn{3}{c}{ Aspidichthys ingens } \\
\cline { 2 - 5 } & PGI-NRI & MWG UW & Muz. PGI & WNaZ/S/4/142 \\
& $5 . I I .89$ & ZI/43/0045 & 1809. II.17 & \\
\hline Conodont zone & $\begin{array}{l}\text { Palmatolepis } \\
\text { punctata }\end{array}$ & $\begin{array}{l}\text { Palmatolepis } \\
\text { linguiformis }\end{array}$ & $\begin{array}{l}\text { Palmatolepis } \\
\text { linguiformis }\end{array}$ & $\begin{array}{l}\text { Palmatolepis } \\
\text { rhenana }\end{array}$ \\
\hline Median dorsal breadth & 14.2 & 16.5 & 23.8 & 16.7 \\
Median dorsal length & 14.3 & 27.0 & 32.0 & 13.75 \\
Median dorsal thickness & 3.8 & 2.9 & 5.35 & 4.7 \\
Tubercle height & $1.8-3.0$ & 1.4 & & 1.5 \\
Tubercle diameter & $2.0-4.0$ & 5.0 & $2.0-2.5$ & $1.0-3.0$ \\
Number of tubercles on & 101 & & 72 & \\
25 cm & & & & 3.0 \\
Crest breadth & & & & 8.2 \\
Crest length & & & & \\
\hline
\end{tabular}

Table 2. Distribution of the stratigraphical occurrence of described specimens and diagrams showing Palmatolepis and Icriodus conodonts percentage share. Abbreviations: E - early; M - middle; L late; $\mathrm{Pa}$ - Palmatolepis; Icr - Icriodus.

\begin{tabular}{|c|c|c|c|c|c|}
\hline \multicolumn{3}{|c|}{$\begin{array}{c}\text { Devonian stage } \\
\text { and conodont zones }\end{array}$} & \multicolumn{3}{|c|}{$\begin{array}{c}\text { Occurrence of } \\
\text { Aspidichthys ingens }\end{array}$} \\
\hline & & & Wietrznia & Kowala & Płucki \\
\hline 晃 & \multicolumn{2}{|l|}{ P. triangularis } & & & \\
\hline \multirow{8}{*}{ 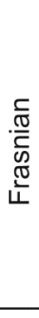 } & $P$. linguformis & & & & \\
\hline & $P$. rhenana & $\frac{\mathrm{L}}{\mathrm{F}}$ & & & \\
\hline & P. jamieae & & & & \\
\hline & P. hassi & $\frac{\mathrm{L}}{\mathrm{F}}$ & & & \\
\hline & P. punctata & & & & \\
\hline & P. transitans & & Icr & & \\
\hline & \multirow{2}{*}{$\begin{array}{l}\text { Palmatolepis } \\
\text { falsiovalis }\end{array}$} & L & & & \\
\hline & & $E$ & & & \\
\hline
\end{tabular}

Specimens from Wietrznia and Kowala were found in debris, and conodont analysis was necessary to determine age; however, it was possible to determine their position precisely in the profile. The limestone from Wietrznia quarry was dated as Palmatolepis punctata (middle Frasnian) and was described by Szulczewski (1971, Fig. 5). The conodont zone analysis of marly limestone from Kowala quarry showed Palmatolepis rhenana zone (upper Frasnian) and was described by Racki et al. (2002, Fig. 2c).

The last locality is Płucki near Łagów, about $36 \mathrm{~km}$ east of Kielce (Fig. 1). There are two outcrops located in the southeastern neighbourhood of the village of Łagów, on the slope of Łagowica Valley, in the eastern fragment of the KielceŁagów Synclinorium. In the Upper Devonian sequence, the so-called Łagów Beds consist of carbonate rocks (limestones and shales) as well as distinctive horizons of lower and upper
Kellwasserkalk built up with classic black bituminous limestones. These two horizons are thought to be connected with anoxic episodes during the Late Devonian (Janiszewska et al., 2007; Szrek, 2007; Szrek and Ginter, 2007, 2008; Rakociński et al., 2016).

Fish remains from Płucki are best preserved within the collection of all Aspidichthys specimens and were collected in situ from the section. They occur in the outcrop with the upper Kellwasserkalk horizon. The outcrop is about $3 \mathrm{~m}$ deep and exposes limestones, marly limestones, marls, and shales. The sequence is strongly disturbed by the presence of a Devonian underwater landslide ascertained very recently (P. Szrek and S. Salwa, personal communication, 2014). The black Kellwasserkalk limestone is about $0.5 \mathrm{~m}$ thick and consists of several discontinuity events (Janiszewska et al., 2007; Szrek, 2007; Szrek and Ginter, 2007, 2008; Rakociński et al., 2016). The lower, entirely Frasnian part (up to $30 \mathrm{~cm}$ ) is characterized by a marl at the bottom with gradual changes upwards into limestone. Fish fossils are quite common, and large armours of Aspidichthys placoderms are most numerous. The middle part (up to $10 \mathrm{~cm}$ ) is the most fossiliferous and is particularly rich in cephalopods and minute arthrodire placoderms. According to precise analysis of Janiszewska et al. (2007) the Frasnian-Famennian boundary is situated within this part of the horizon. The uppermost part entirely belongs to the Famennian and is characterized by numerous invertebrates and fishes, but no Aspidichthys was ascertained here.

\section{Systematic palaeontology}

Synonym list: Placodermi M'Coy, 1848

Arthrodira Woodward, 1891

Brachythoraci Gross, 1932

Aspidichthys Newberry, 1873 incertae sedis 
Type species: Aspidichthys ingens von Koenen, 1883

Aspidichthys ingens von Koenen, 1883

(Figs. 2-5)

1933 Anomalichthys magnus n. sp., W. Gross, pp. 4244, Tab. 6, Fig. 4.

1933 Aspidichthys? ingens. - W. Gross, pp. 48-49, Tab. 6, Fig. 5.

1937 Aspidichthys ingens. - W. Gross, p. 40, Pl. 5, Fig. 4. 1956 Aspidichthys clavatus. - G. W. Sinclair \& D. R. Walker, pp. 135-137, Figs. 1-3.

1957 Anomalichthys ingens. - J. Kulczycki, pp. 333-335, Figs. 1-3.

1973 Aspidichthys cf. ingens Koenen, H.-P. Schultze, pp. 69-75, Pl. 2A-D.

1976 Aspidichthys. - J. P. Lehman, pp. 21-22, Pl. 9, Figs. C-D.

1978 Aspidichthys ingens. - R. Denison, p. 103, Fig. 84.

Material: Four fragments of median dorsal plates: Muz. PGI-NRI 5.II.89 (Kulczycki, 1957, Fig. 2), MWG UW ZI/43/0045 (Figs. 2-3), Muz. PIG 1809.II.17 (Fig. 4), and an incomplete median dorsal plate WNaZ/S/4/142 (Fig. 5). See Table 1 for detailed measurements and Table 2 for horizons.

Locality and age: Muz. PGI-NRI 5.II.89: middle Frasnian (Palmatolepis punctata conodont zone) of Wietrznia Quarry in Kielce; WNaZ/S/4/142: upper Frasnian (Palmatolepis rhenana conodont zone) of Kowala Quarry; Muz. PIG 1809.II.17, MWG UW ZI/43/0045: upper Frasnian (Palmatolepis linguiformis conodont zone) of Płucki near Łagów.

Description: Specimen Muz. PGI-NRI 5.II.89 (Kulczycki, 1957, Pl. 9, Fig. 2) shows the anterior part of a median dorsal plate with clearly visible ornamentation. The median dorsal is broken and lacks its natural boundaries; the carinal process on the visceral side typical of brachythoracids is not visible. The ornamentation consists of smooth and rounded tubercles that are irregularly arranged. The diameter of tubercles varies between 2 and $4 \mathrm{~mm}$, and the height varies between 1.8 and $3 \mathrm{~mm}$. The number of tubercles on $25 \mathrm{~cm}^{2}$ of the shield is approximately 101 .

This specimen described above was taken into consideration by Kulczycki (1957) but not illustrated. Nevertheless, it served as the source of material from which conodonts were prepared. Specimens described below were collected very recently and have not been published before.

The specimen MWG UW ZI/43/0045 (Figs. 2-3) shows partially preserved median dorsal plate and left posterior dorsolateral plate. The plate is strongly arched, enclosing at an angle of ca. $120^{\circ}$ in the anterior half and rounded and flattened out in the posterior half. The external side of the plate is covered with large and rounded tubercles irregularly arranged. Tubercles are $5 \mathrm{~mm}$ in diameter at their largest and
$1.4 \mathrm{~mm}$ in height. The number of tubercles on $25 \mathrm{~cm}^{2}$ was not counted because a large part of them are eroded. The left posterior dorsolateral plate is preserved in the same block of rock and could belong to the same individual. This plate has the natural boundary along the lower, left, and upper margin, the last of which being an overlapping surface for the median dorsal plate (Fig. 2). The lateral line is well preserved, especially on left half of the plate, and is visible from the left anterior corner, close to the upper margin and border with median dorsal plate for about one-third of its length, and then turns and extends onto the right margin in approximately the middle of the plate. The posterior part of this plate is still covered by the matrix, and the most posterior margin lies under the anterior part of the median dorsal plate. The course of the lateral line is additionally marked with a longitudinal arrangement of tubercles.

Specimen no. Muz. PGI-NRI 1809.II.17 (Fig. 4) is represented by a median dorsal plate. The plate is very fissured and curved. The angle between the left and right sides is $120^{\circ}$ in the anterior half (Fig. $4 \mathrm{~b}$ ); the posterior part is flattened secondarily. On the lateral part of the shield a natural boundary is preserved, but the keel is invisible. The shield is ornamented with irregularly arranged and not widely removed from each of the other tubercles (Fig. 4d). The tubercles are rounded and are 2 to $2.5 \mathrm{~mm}$ in diameter. They are also more or less the same sizes on the entire surface of the shield. The height of tubercles was not measured because of the high abrasion of them. The number of tubercles on $25 \mathrm{~m}^{2}$ of the shield is 72 . The specimen additionally included a fragment of unidentified other plate, probably a part of one of the lateral plates of the trunk shield (breadth $3.65 \mathrm{~cm}$, length $5.5 \mathrm{~cm}$ ) with the same type of ornamentation. In the lateral and posterior regions of the median dorsal plate they are larger and sometimes also irregularly confluent.

The specimen (WNaZ/S/4/142, Fig. 5) shows the anterior part of the median dorsal plate. The plate is thick (about $4.7 \mathrm{~cm}$ ) and the visceral surface is not visible. The natural anterior margin is preserved. The ornamentation consists of round and smooth tubercles without regular arrangement. Tubercles are about 1 to $3 \mathrm{~mm}$ wide in diameter and $1.5 \mathrm{~cm}$ in height. The number of tubercles on $25 \mathrm{~cm}^{2}$ have not been counted because a large part of them are eroded.

In the anterior part of those plates (MWG UW ZI/43/0045, Figs. 2-3; WNaZ/S/4/142, Fig. 5), the small crest occurs. The crest is in the form of a median longitudinal thickening of steep sides, ascending gradually and reaching a height of about $25 \mathrm{~mm}$ in the anteriormost margin. The symmetry plane of this crest meets the plane of the shield at an angle of $30^{\circ}$. The surface of this crest is covered with tubercles similar to the rest of the shield. The crest was originally present on specimen Muz. PGI-NRI 1809.II.17 but has been lost because of damage to this region of the shield (Fig. 4a).

Counting of tubercles on the described specimens revealed that a younger specimen from Płucki (Muz. PGI-NRI 1809.II.17) has a lower number of tubercles than the older 


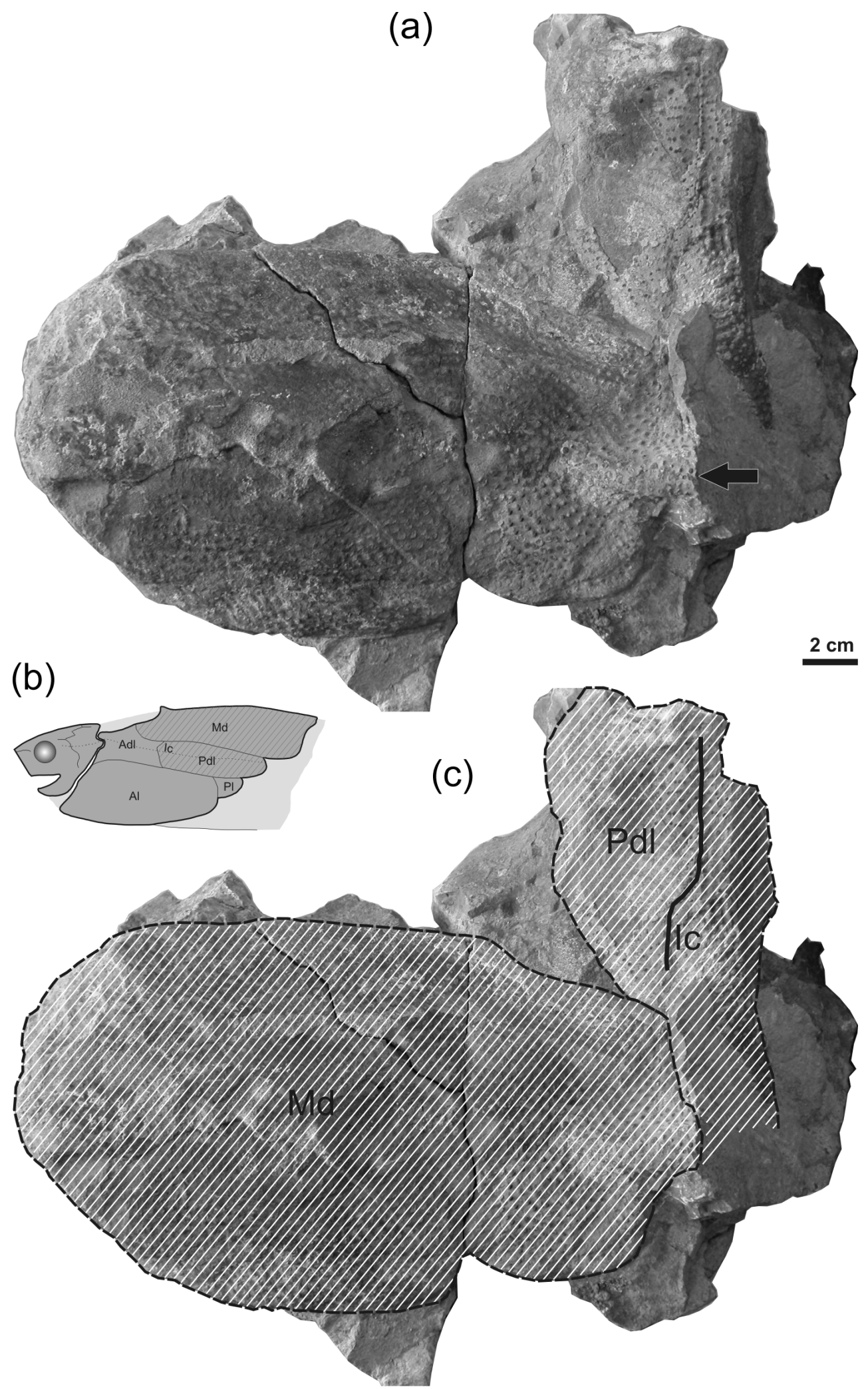

Figure 2. Specimen no. MWG UW ZI/43/0045. (a) Dorsal view of the specimen (arrow shows anterior part), (b) lateral view of the reconstructed armour (preserved parts are marked), and (c) dorsal view of specimen with particular plates and elements marked with lines. 

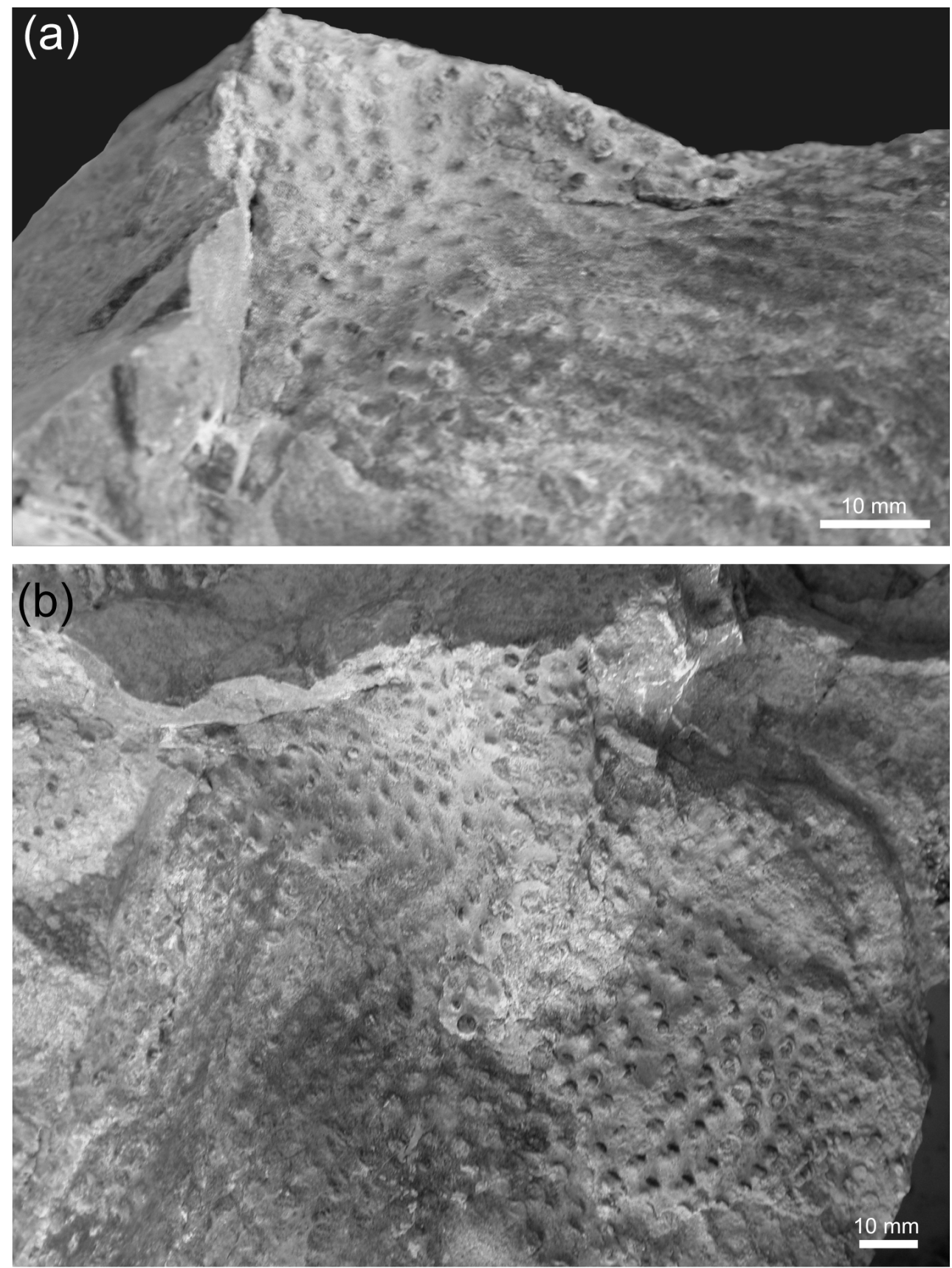

Figure 3. Specimen no. MWG UW ZI/43/0045. Magnified anterior part of the median dorsal plate in (a) lateral and (b) dorsal view.

specimen from Wietrznia Quarry (Muz. PGI-NRI 5.II.89) (see Table 1).

Discussion: Already known species of the genus Aspidichthys are represented by A. ingens Koenen, 1883 and A. clavatus Newberry, 1873 (see the discussion by Denison, 1978, p. 103). The presented material is similar in shape and morphology to the specimens described by Kulczycki (1957) but is characterized by smaller tubercles. Tubercles in Kulczycki's (1957) material reach up to $10 \mathrm{~mm}$, while in the studied material they do not extend to even $5 \mathrm{~mm}$ in diameter. On specimen $\mathrm{WNaZ} / \mathrm{S} / 4 / 142$, tubercles reach the smallest sizes even though this specimen represents the largest individual among all analysed specimens. The characters observed on studied specimens are very peculiar and correspond well to randomly distributed tubercules. Tubercules have stellate base of $5 \mathrm{~mm}$ in diameter at their largest. The plate is thick, arched and elongated. Those features have been observed and illustrated by previous authors (Newberry, 1873, Pl. 35, Fig. 1; Whiteaves, 1892, 


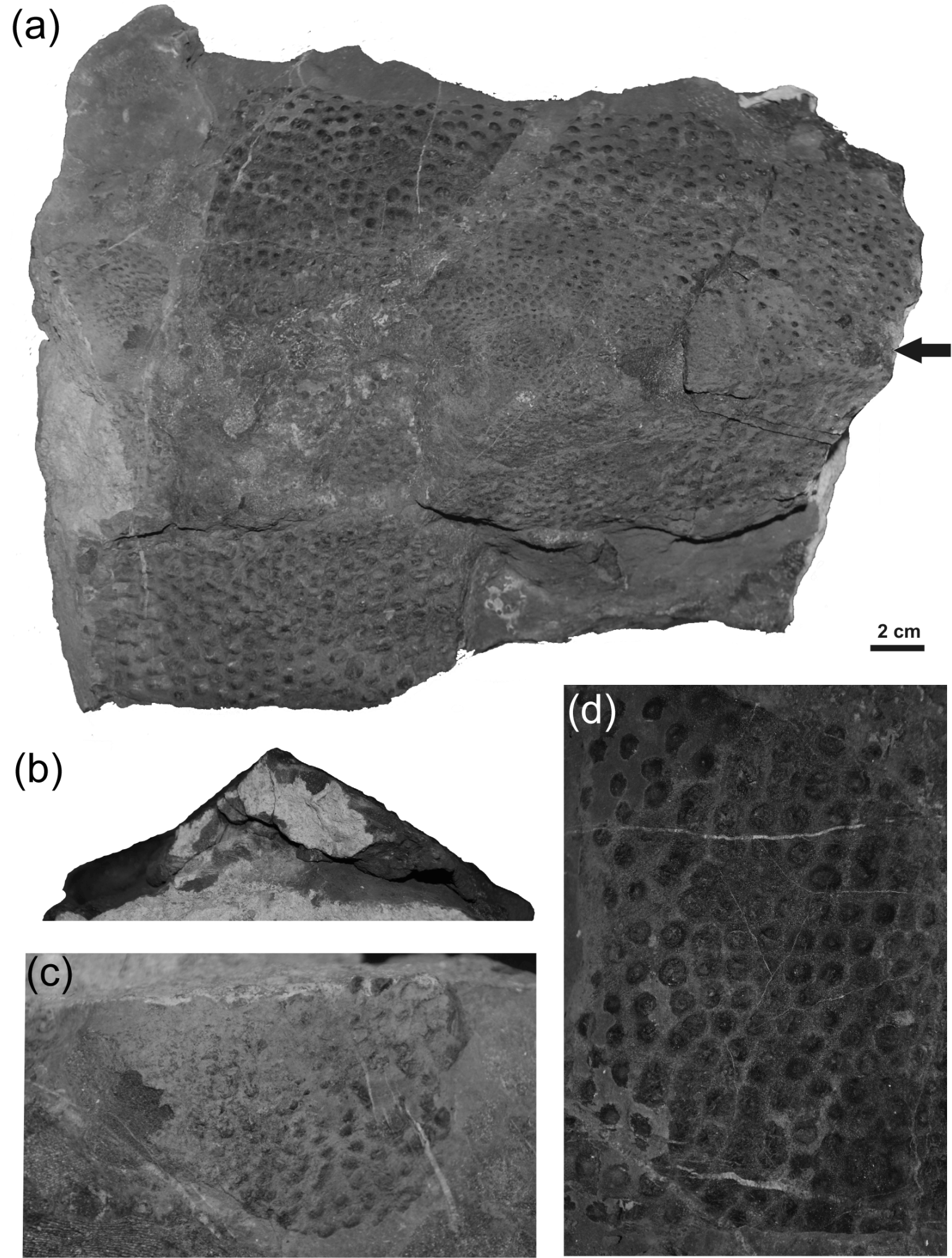

Figure 4. Specimen no. Muz. PIG 1809.II.17. (a) Dorsal view of the median dorsal plate (arrow shows anterior part), (b) median dorsal plate in anterior view, (c) one of the armour plates (probably the posterior lateral plate), and (d) magnified area of the median dorsal plate showing the ornamentation. 

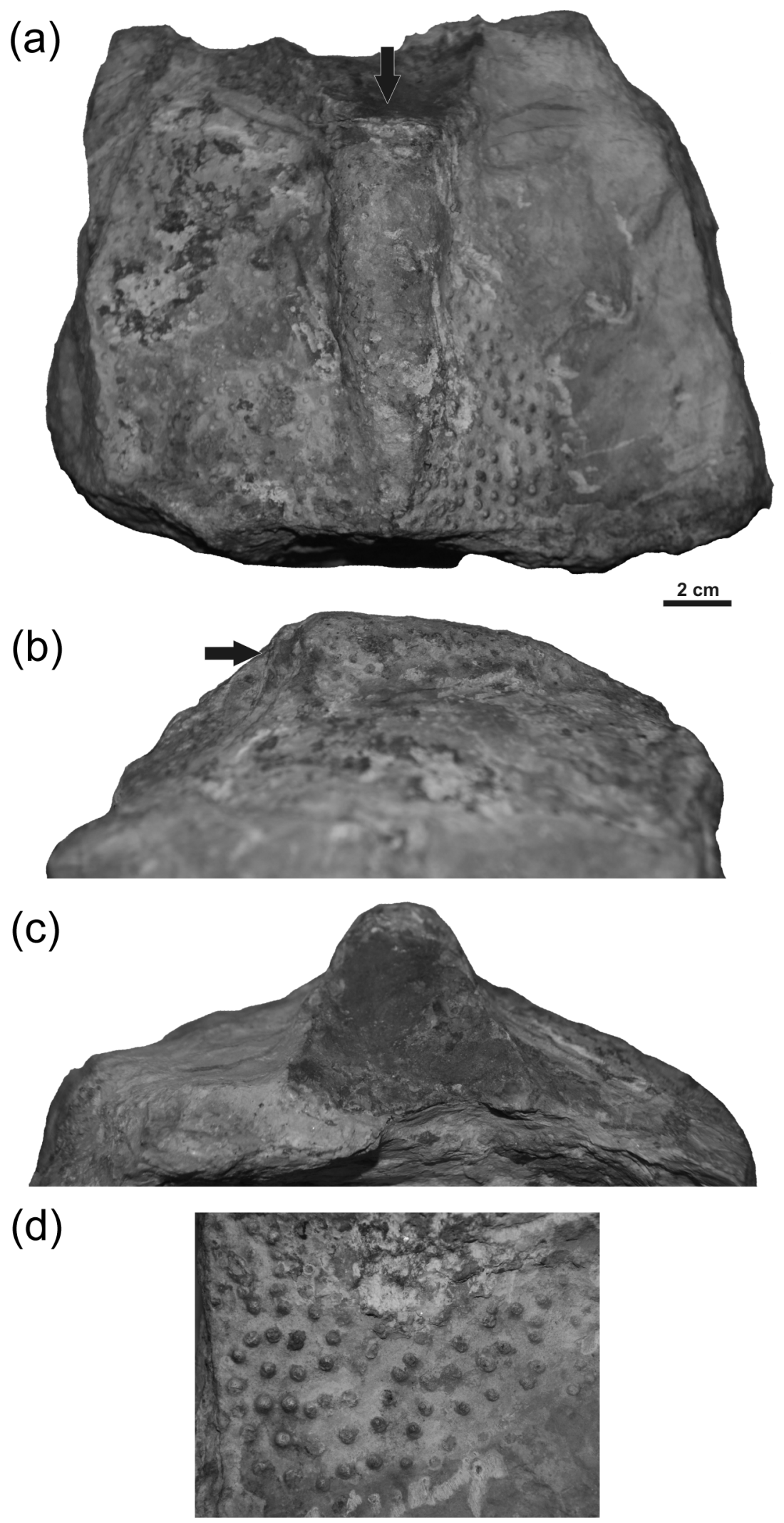

Figure 5. Specimen no WNaZ/S/4/142, anterior part of the median dorsal plate. (a) Dorsal view, (b) lateral view (arrow shows anterior part), (c) anterior view, and (d) magnified area of the median dorsal plate showing the ornamentation. 
p. 355; Gross, 1933, Tab. 6, Fig. 4; Sinclair and Walker, 1956, Fig. 1-3; Kulczycki, 1957, Pl. 1-3; Schultze, 1973), as well as preliminary characterized material from the Holy Cross Mountains (Szrek, 2009). All specimens described herein are different from those discussed by Schultze (1973, Pl. 2, Fig. a-b) by clearly larger distances between tubercles and thus are more reminiscent of those illustrated by Newberry (1873, Pl. 35, Fig. 1), Gross (1933, Tab. 6, Figs. 4-5), Sinclair and Walker (1956, Fig. 1), and Kulczycki (1957, Pl. 11, Figs. 2-3). Differences could lie in a local palaeogeographic morphological variations suggested by Kulczycki (1957) rather than sizes of particular individual and species differentiation.

The specimens where the anterior margin of the median dorsal plate is preserved (MWG UW ZI/43/0045, Figs. 2-3; $\mathrm{WNaZ} / \mathrm{S} / 4 / 142$, Fig. 5a-c) show a more rounded margin in the part where it turns posteriorly than on the specimen illustrated by Sinclair and Walker (1956, Figs. 1-2), on which this part turns at almost a right angle. This region is visible only in the specimens MWG UW ZI/43/0045 and WNaZ/S/4/142 and those of Sinclair and Walker (1956, Figs. 1-2). Moreover, the carinal process mentioned by Kulczycki (1957) and Schultze (1973) is not accessible for investigation because it is not visible in the new material from the Holy Cross Mountains, making a detailed comparison difficult. However, other morphological features of the external side of the median dorsal plates (overall shape longer than wide, ornamentation composed of large tubercles, thickness of bones that are arched and which enclose at an angle of $120^{\circ}$ of the median dorsal plate) correspond to other described specimens (Sinclair and Walker, 1956; Kulczycki, 1957) and confirm identification of Aspidichthys ingens Koenen, 1895.

The median dorsal plate of species Aspidichthys ingens represented by specimen no. WNaZ/S/4/142 is not complete, but species-related features are preserved (e.g. large, rounded irregularly arranged tubercles and relatively thick shield; Denison, 1978) which are commonly observed on the plates and suggest that the plate belongs to this species. The studied specimen has smaller tubercles (1-3 mm in diameter) than the specimens described by Kulczycki (1957), which have tubercles of even $10 \mathrm{~mm}$ in diameter. This specimen can be compared with Aspidichthys described by Schultze (1978, Pl. 3), where the ornamentation contains tubercles about $4 \mathrm{~mm}$ in diameter; however, the studied specimen shows a large keel. In the material described by Schultze (1978), an inconsiderable bump occurs on the anterior part of the shield. This bump is clearly visible on almost all specimens studied.

The studied remains occur in the pelagic facies, suggesting that Aspidichthys lived in a deep-water environment (Ivanov and Ginter, 1997; Szrek, 2006) as active predators would have had a demersal lifestyle (Janiszewska et al., 2007; Szrek, 2007). The conodont analysis shows that placoderms from Wietrznia Quarry lived in slightly shallower water than those from Kowala Quarry. In the sample from the punctata zone (Wietrznia Quarry), Icriodus is more numerous than in the sample from the early rhenana zone (Kowala Quarry), where Icriodus elements are in the minority, which suggests a deeper environment. In the sample from Wietrznia Quarry (punctata conodont zone) there were 10 Icriodus elements and 19 Palmatolepis elements. In the sample from Kowala Quarry (rhenana conodont zone) there were 25 elements of Icriodus and 326 elements of Palmatolepis. Sample form Płucki revealed 33 Icriodus and 44 Palmatolepis elements. For details, one can refer to Table 2, which indicates a progressive and stepwise deepening of the environment and is correlated with the synsedimentary block tectonics and permanent growth of the sea level in the studied area during the Frasnian suggested by previous authors (e.g. Szulczewski, 1995). Analyses of the Płucki section (Racki et al., 2002; Woroncowa-Marcinowska, 2006; see Table 2) demonstrated a deep-sea environment in the linguiformis conodont zone. Moreover, the regression at the Frasnian-Famennian boundary has been suggested based on the percentage share of Palmatolepis and Icriodus elements (Janiszewska et al., 2007), which could be correlated with global changes in sea level (McGhee Jr., 2013). The conjunction of the regression and environmental changes during the reef fauna crisis could have led to the disappearance of Aspidichthys during the Frasnian to Famennian transition.

The analysis of the placoderm fauna from the Upper Kellwasserkalk of Płucki shows similarities to the contemporary fauna from Bad Wildungen. For 14 genera ascertained in Płucki (Szrek, 2008, 2009), 9, including Aspidichthys, are common to Bad Wildungen. This is most likely directly related to the short palaeogeographic distance between both localities. Exhaustive analysis of palaeobiogeographic distribution of different placoderm taxa also from Morocco, France, Iran, and Australia suggests vicinities between all of these areas without a significant barrier (Rücklin, 2010) for bottom-dwelling fishes (e.g. deep ocean).

\section{Conclusions}

Detailed description of Aspidichthys placoderm from the Kellwasserkalk locality in the Holy Cross Mountains is provided for the first time. The remains constitute the most important placoderm assemblage associated with a single genus from the Devonian of the Holy Cross Mountains. The described specimens belong to Aspidichthys ingens Koenen, 1883.

Previous stratigraphic occurrences of specimens mentioned by Gorizdro-Kulczycka (1934), Kulczycki (1957, p. 287), and Ivanov and Ginter (1997, Table 1) based on old lithostratigraphic zonation are now updated to standard conodont zonation (Ziegler and Sandberg, 1990). Analysis shows that stratigraphic occurrence of this genus is limited to the Frasnian, in the Holy Cross Mountains. 
Environmental analysis based on conodont biofacies shows that Aspidichthys placoderms have adapted to a deepening environment as their fossils occur in Icriodusdominated as well as in Palmatolepis-dominated facies. The occurrence of the same taxa in many different locations (Bad Wildungen, Morocco, North America, Iran, Holy Cross Mountains) is in agreement with the absence of a biogeographic barrier effectively separating particular ecosystems postulated by Rücklin (2010).

\section{Data availability}

Specimens described herein are housed at the following institutions: Geological Museum of the Polish Geological Institute-National Research Institute in Warsaw, Poland (collection number Muz. PGI-NRI 5.II and 1809.II); Faculty of Geology, University of Warsaw, Poland (collection number MWG UW ZI/43); and Faculty of Earth Sciences, University of Silesia in Sosnowiec, Poland (collection number $\mathrm{WNaZ/S/4).}$

Acknowledgements. We thank Vincent Dupret and the anonymous reviewer for very useful revision and helpful comments. We are grateful to M. Rakociński (University of Silesia, Sosnowiec) and Ł. Gągała (Georex, Argenteuil) for providing a part of studied collection; to Z. Bełka (Adam Mickiewicz University, Poznań) for help during conodonts identification and to B. Berkowski (Adam Mickiewicz University, Poznań); and G. Gierliński (Polish Geological Institute-National Research Institute, Warsaw), who kindly revised an early version of the manuscript. Piotr Szrek was funded by a Polish Geological Institute - National Research Institute (grant number 61.2401.1301.00.0).

Edited by: F. Witzmann

Reviewed by: V. Dupret and one anonymous referee

\section{References}

Berkowski, B.: Famennian Rugosa and Heterocorallia from Southern Poland, Palaeontologia Polonica, 61, 3-88, 2002.

Denison, R. H.: Handbook of Paleoichthyology, in: Vol. 2 - Placodermi, edited by: Schultze, H.-P., Gustav Fischer Verlag, Stuttgard-New York, 1-128, 1978.

Gorizdro-Kulczycka, Z.: Sur les Ptyctodontidae du Dévonien Supérieur du Massif de S-te Croix, Prace Państwowego Instytutu Geologicznego, 3, 1-38, 1934.

Gross, W.: Die Arthrodira Wildungens, Geologische und Palaeontologische Abhandlungen, 19, 5-61, 1932.

Gross, W.: Die Wirbeltiere des rheinischen Devons, Abhandlungen der Preusischen Geologischen Landesanstalt, 154, 1-83, 1933.

Gross, W.: Die Wirbeltiere des rheinischen Devons, Abhandlungen der Preusischen Geologischen Landesanstalt, 176, 1-83, 1937.

Ivanov, A. and Ginter, M.: Comments on the Late Devonian placoderms from the Holy Cross Mountains (Poland), Acta Palaeontol. Pol., 42, 413-426, 1997.
Janiszewska, K., Szrek, P., and Woroncowa-Marcinowska, T.: Zapis zdarzeń biotycznych na pograniczu frańsko-fameńskim w Płuckach koło Łagowa (Biotic events record at the FrasnianFamennian transition in Płucki near Łagów), edited by: Żylińska, A., XX Konferencja Naukowa Paleobiologów i Biostratygrafów PTG, Granice Paleontologii. Warszawa, 63-66, 2007 (Polish).

Joachimski, J. M., Ostertag-Henning, H., Pancost, H. Strauss, R. D., Freeman, K. H., Littke, R., Damste, J. S., and Racki, G.: Water column anoxia, enhanced productivity and concomitant changes in $\delta^{13} \mathrm{C}$ and $\delta^{34} \mathrm{~S}$ across the Frasnian-Famennian boundary (Kowala - Holy Cross Mountains/Poland), Chem. Geol., 175, 109-131, 2001.

Koenen, A. V.: Beitrag zur Kenntniss der Placodermen des norddeutschen Oberdevon's, Abhandlungen Königliche Gesellschaft der Wissenschaften, Gottingen, 30, 1-40, 1883.

Kowalczewski, Z.: Main geological problems of the Lower Devonian in the Świętokrzyskie Mts., Geol. Q., 15, 263-283, 1971 (Polish with English summary).

Kulczycki, J.: Upper Devonian fishes from the Holy Cross Mountains, Acta Palaeontol. Pol., 2, 285-380, 1957.

McGhee Jr., G. R.: When the Invasion of Land Failed: The Legacy of the Devonian Extinctions, Columbia University Press, New York, 2013.

M'Coy, F.: On some new fossil fish of the Carboniferous period, Annals and Magazine of Natural History, 2, 1-10, 1848.

Miles, R. S.: A large arthrodire plate from Chautauqua County, New York, Arkiv för zoologii, Kungliga Svenska Vetenskaps, Akademiens Handlingar, 16, 545-550, 1965.

Narkiewicz, M., Racki, G., Skompski, S., and Szulczewski, M.: Zapis procesów i zdarzeń w dewonie i karbonie Gór Świętokrzyskich (Processes and events record in the Devonian and Carboniferous of the Holy Cross Mountains), edited by: Żylińska, A., XX Konferencja Naukowa Paleobiologów i Biostratygrafów PTG, Granice Paleontologii, Warszawa, 51-77, 2006 (Polish).

Newberry, J. S.: The Classification and Geological Distribution of Our Fossil Fishes, Palaeontology of Ohio, 1, 247-355, 1873.

Racki, G., Racka, M., Matyja, H., and Devleechouwer, X.: The Frasnian/Famennian boundary interval in the South PolishMoravian shelf basins: integrated event-stratigraphical approach, Palaeogeogr. Palaeocl., 181, 251-297, 2002.

Rakociński, M., Pisarzowska, A., Janiszewska, K., and Szrek, P.: Depositional conditions during the Lower Kellwasser Event (Late Frasnian) in the deep-shelf Łysogóry basin of the Holy Cross Mountains (Poland), Lethaia, 49, 571-590, 2016.

Rücklin, M.: A new Frasnian placoderm assemblage from the eastern Anti-Atlas, Morocco, and its palaeobiogeographical implications, Palaeoworld, 19, 87-93, 2010.

Schultze, H. P.: Large Upper Devonian Arthrodires from Iran, Fieldana Geology, 23, 53-78, 1973.

Sinclair, G. W. and Walker, D. R.: Redescription of Aspidichthys: Arthrodira, Devonian, Ohio J. Sci., 56, 135-137, 1956.

Szrek, P.: Zróżnicowanie facjalne a skamieniałości późnodewońskich plakodermów w Górach Świętokrzyskich (Facies variabilty and Late Devonian placoderms fossils in the Holy Cross Mountains), Przegląd Geologiczny 54, 521-524, 2006 (Polish).

Szrek, P.: Ryby pancerne a zapis górnego zdarzenia Kellwasser w Płuckach koło Łagowa (Placoderms and upper Kellwasser event in Płucki near Łagów), edited by: Żylińska, A., XX Konferencja 
Naukowa Paleobiologów i Biostratygrafów PTG, Granice Paleontologii, Warszawa, 133-134, 2007 (Polish).

Szrek, P.: Vertebrates from the upper Kellwasser limestone, Frasnian-Famennian boundary beds (Upper Devonian) of the Holy Cross Mountains (Poland), J. Vertebr. Paleontol., 28, p. 150, 2008.

Szrek, P.: Placoderm fishes from the Devonian of the Holy Cross Mountains, Unpublished $\mathrm{PhD}$ dissertation, University of Warsaw, Warsaw, 144 pp., 2009 (Polish).

Szrek, P. and Ginter, M.: Poziomy wapieni typu Kellwasserkalk w Płuckach koło Łagowa (Kellwasser-like limestone horizons in Płucki near Łagów), edited by: Żylińska, A., XX Konferencja Naukowa Paleobiologów i Biostratygrafów PTG, Granice Paleontologii, Warszawa, 157-161, 2007 (Polish).

Szrek, P. and Ginter, M.: Kellwasser layers at Płucki near Łagów, Ichthyolith Issues, Special Publication, 11, 47-50, 2008.

Szulczewski, M.: Upper Devonian conodonts, stratigraphy and facial development in the Holy Cross Mts., Acta Geol. Pol., 21, 1-129, 1971.

Szulczewski, M.: Światowe i regionalne zdarzenia w zapisie stratygraficznym pogranicza franu i famenu Gór Świętokrzyskich (Worldwide and regional events in stratigraphic record of the Franian-Famennian boundary in the Holy Cross Mountains), Przegląd Geologiczny, 11, 551-557, 1989 (Polish).
Szulczewski, M.: Depositional evolution of the Holy Cross Mountains in the Devonian and Carboniferous - a review, Geol. Q., 39, 471-488, 1995.

Szulczewski, M., Bełka, Z., and Skompski, S.: The drowning of a carbonate platform: an example from the DevonianCarboniferous of the southwestern Holy Cross Mountains, Poland, Sediment. Geol., 106, 21-49, 1996.

Whiteaves, J. F.: The fossils of the Devonian rocks of the islands, shores or immediate vicinity of Lakes Manitoba and Winnipegosis, Geological Survey of Canada, Contributions to Canadian palæontology, 1, 255-359, 1892.

Woodward, A. S.: Catalogue of the fossil fishes in the British Museum (Natural History), Part II, 1-567, London, 1891.

Woroncowa-Marcinowska, T.: Upper Devonian goniatites and cooccurring conodonts from the Holy Cross Mountains: studies of the Polish Geological Institute collections, Ann. Soc. Geol. Pol., 76, 113-160, 2006.

Ziegler, W. and Sandberg, C. A.: The Late Devonian standard conodont zonation, Courier Forschungsinstitut Senckenberg, 121, 1115, 1990. 